\title{
HYDRODYNAMIC KELVIN-VOIGT MODEL TRANSPORTATION SYSTEM
}

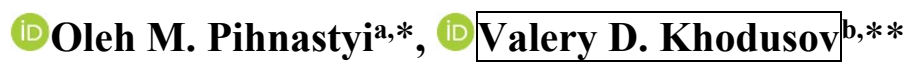 \\ ${ }^{a}$ National Technical University "KhPI" \\ Kyrpychev str. 2, Kharkiv, Ukraine \\ ${ }^{b}$ V.N. Karazin Kharkiv National University, Kharkiv, Ukraine \\ *Corresponding Author: pihnastyi@gmail.com,**E-mail:vkhodusov@ukr.net \\ Received August 08, 2020; accepted September 19, 2020
}

The hydrodynamic Kelvin-Voigt model of production systems with a flow method of organizing production is considered. The main macro parameters of the state of the production line and the relationship between them are determined. The analysis of the main characteristics of models of elastic elements, which are used to analyze the occurrence of the dynamic stresses in a moving conveyor belt, is presented. A boundary value problem for elastic longitudinal vibrations in a conveyor belt with a moving material is formulated. It is assumed that the deformation of the conveyor belt element corresponds to the Kelvin-Voigt model and there is no sliding of the moving material on the belt. When determining the forces of resistance to motion acting on an element of the belt, the recommendations of DIN 22101: 2002-08 were used. The analysis of the Kelvin-Voigt model of the elastic element is carried out and the distinctive features of the model are demonstrated. The justification of the choice of the Kelvin-Voigt model of an elastic element for describing the process of occurrence of the longitudinal vibrations in a conveyor belt is given. The dependence of the non-uniform flow of material and the magnitude of tensions in the belt is estimated. An expression is written for the speed of propagation of disturbances along a moving conveyor belt with the material. The reasons for the acceleration and deceleration of the conveyor belt associated with the uneven supply of material at the entrance of the transport system are determined. The relationship between the speed of a conveyor belt and the mass of material along a section of the conveyor is demonstrated. It is shown that an increase in the power of the electric motor at the start and acceleration of the conveyor belt, as well as a decrease in power during the braking and stopping of the conveyor belt, is the cause of the appearance of dynamic stresses in it. The characteristic phases of the initial movement of the conveyor belt with the material are analyzed. The process of occurrence of dynamic tensions with the constant and variable acceleration of the conveyor belt for the phase of acceleration and deceleration of the conveyor belt is investigated. For the analysis, a dimensionless model of a conveyor line was used. An expression is obtained for static and dynamic tensions in the conveyor belt. The amplitude of oscillations of dynamic stresses and the characteristic time of damping of oscillations in a conveyor belt is estimated. A quadratic dependence of the speed of damping of a wave of dynamic tensions with an increase in the oscillation frequency is demonstrated. An inversely proportional dependence of the characteristic decay time of the generated dynamic tensions on the value of the viscosity coefficient of the composite material of the conveyor belt is shown.

KEY WORDS: hydrodynamic model of a transport system, two-moment description, Hooke model, balance equations, PDE production model

In article [1], the hydrodynamic Hooke's model of a transport system is considered, which was used to analyze the mechanism of the occurrence of longitudinal vibrations in a conveyor belt when material moves along a transportation route. To construct a model of the transport system, the equations of two-moment description (2) were used in the form $[1,2]$ :

$$
\begin{gathered}
\frac{\partial[\chi]_{0}(t, S)}{\partial t}+\frac{\partial[\chi]_{1}(t, S)}{\partial S}=\delta(S) \lambda(t), \\
{[\chi]_{0}(t, S) \frac{\partial\langle\mu\rangle}{\partial t}+[\chi]_{1}(t, S) \frac{\partial\langle\mu\rangle}{\partial S}=[\chi]_{0}(t, S) f(t, S), \quad\langle\mu\rangle=\frac{[\chi]_{1}(t, S)}{[\chi]_{0}(t, S)},}
\end{gathered}
$$

where $[\chi]_{0}(t, S),[\chi]_{1}(t, S)$ are respectively, the density of the material and the flow of material at the moment in time $t$ at the point of the transport route, which is determined by the coordinate $S, S \in\left[0, S_{d}\right] ; S_{d}$ is the length of the transport route; $\lambda(t)$ is the intensity of material receipt at the entrance of the transport system at the point $S=0$; $f(t, S)$ is the force that acts on the material per unit mass of the material and the belt [3]; $\delta(S)$ is Dirac delta function. We will assume that the specific density of the conveyor belt is constant and equal $[\chi]_{0 C}$, the conveyor section is located horizontally, and the material does not crumble from the conveyor belt.

The force acting on the section $d S$ of the density conveyor belt $[\chi]_{0 C}=$ const, on which the material with density $[\chi]_{0}(t, S)$ is located can be calculated as follows [1, Fig. 1]:

$$
\begin{aligned}
& f(t, S) d m=R(t, S+d S)-R(t, S)-d F_{W}, \quad d m=\left([\chi]_{0}(t, S)+[\chi]_{0 C}\right) d S, \\
& R(S)=\sigma(t, S) B h,
\end{aligned}
$$


where $d m$ is the total mass acting on the belt; $B$ is conveyor belt width; $h$ is conveyor belt height; $\sigma(t, S)$ is conveyor belt tensions; $F_{W}$ is sum of total resistances to belt movement [1]:

$$
\mathrm{F}_{\mathrm{W}}=\mathrm{F}_{\mathrm{H}}+\mathrm{F}_{\mathrm{N}}+\mathrm{F}_{\mathrm{St}}+\mathrm{F}_{\mathrm{S}} \text {. }
$$

Descriptions of each component of the secondary resistance (5) are discussed in detail in [1]. Detailed information on the methods for calculating secondary resistances is given in [4].

Primary resistances $\mathrm{F}_{\mathrm{H}}$ are related to the frictional resistance along the conveyor belt, with the exception of specific resistances. The primary resistances $\mathrm{F}_{\mathrm{H}}$, assuming a linear relationship between the resistances and the transported load, are determined by the expression

$$
d \mathrm{~F}_{\mathrm{H}}=d S \cdot f_{C} \cdot g_{m}\left([\chi]_{0 R}+\left([\chi]_{0}(t, S)+[\chi]_{0 C}\right) \cos \delta_{C}\right),
$$

$f_{C}$ is the coefficient of resistance to motion, which includes the rolling resistance of the driving rollers and the resistance of the belt being pressed; $g_{m}=9.81\left(\mathrm{~m} / \mathrm{sec}^{2}\right) ; \quad[\chi]_{0 R}$ is linear load from rotating parts; $\delta_{C}$ is the angle of inclination of the section of the conveyor section. The force $\mathrm{F}_{\mathrm{N}}$, taking into account the influence on the movement of secondary resistances, can be expressed through the value of the primary resistance to movement $F_{H}[4]$ :

$$
\mathrm{F}_{\mathrm{N}}=(C-1) \mathrm{F}_{\mathrm{H}}, \quad C \approx 1,05 .
$$

The force $\mathrm{F}_{\mathrm{St}}$, characterizing the gradient resistance of the conveyor belt and transported material [4]

$$
d \mathrm{~F}_{\mathrm{St}}=d S \cdot \sin \delta_{C} \cdot g_{m}\left([\chi]_{0}(t, S)+[\chi]_{0 C}\right)
$$

for a horizontally located conveyor section $\left(\delta_{C}=0\right.$ ) not present.

The calculation of the force $\mathrm{F}_{\mathrm{S}}$, associated with special resistances in the transport system is determined by the design features of the transport system. For most conveyor-type transport systems, it is assumed

$$
\mathrm{F}_{\mathrm{S}}<<\mathrm{F}_{\mathrm{H}} \text {. }
$$

Divide (3) by $d m$

$$
f(t, S)=\frac{1}{\left([\chi]_{0}(t, S)+[\chi]_{0 C}\right)} \frac{\partial R(t, S)}{\partial S}-\frac{1}{\left([\chi]_{0}(t, S)+[\chi]_{0 C}\right)} \frac{\partial F_{W}}{\partial S} .
$$

substituting the result into (2), we obtain an equation that, together with equation (1), determines the propagation of stress disturbances along the conveyor belt, taking into account the distribution of material along the transport route

$$
\frac{\partial\langle\mu\rangle}{\partial t}+\langle\mu\rangle \frac{\partial\langle\mu\rangle}{\partial S}=\frac{1}{\left([\chi]_{0}(t, S)+[\chi]_{0 C}\right)} \frac{\partial R(t, S)}{\partial S}-\frac{1}{\left([\chi]_{0}(t, S)+[\chi]_{0 C}\right)} \frac{\partial F_{W}}{\partial S} .
$$

To solve the system of equations (1), (7), the relationship between the tensions and the relative deformation of the section of the conveyor belt must be known

$$
\sigma(t, S)=f_{\sigma}(\varepsilon(t, S)) .
$$

This dependence is determined by the properties of the composite material from which the conveyor belt is made and is a model of an elastic element.

FORMULATION OF THE PROBLEM

The cost of transporting material from the place of extraction to the place of material processing reaches $20 \%$ of the total cost of mining material [5]. These costs can be significantly increased in the case of underloaded transport systems. This is especially important for long-distance transport systems [6,7]. To reduce unit costs, systems are used to control the speed of the conveyor belt $\langle\mu\rangle$ and the value of the incoming flow $\lambda(t)$ to the input of a separate section from the accumulating bunker. The control of the parameters of the transport system changes the linear density of the material $[\chi]_{0}(t, S)$ along the transportation route. Control algorithms assume the operation of the conveyor section in the mode of acceleration or deceleration of the conveyor belt $[8,9]$. This leads to the generation and propagation of tension disturbances along the conveyor belt [10]. If the maximum permissible tension value of the conveyor belt is 
exceeded, such control modes destroy the transport system. The danger of such situations is relevant at the present time and requires a detailed analysis of the causes of disturbances for conveyor belts made of different materials.

\section{MODEL OVERVIEW}

The process of propagation of tension disturbances along the conveyor belt of the transport system largely depends on the properties of the material from which the conveyor belt is made. An overview of the models of elastic elements for materials of various properties is presented in [9]. The analysis of the main characteristics of elastic element models is presented: Hookean element, Newtonian element, Maxwell element, Kelvin element, Venant element, CDI geometric beam element and CDI five-element. The finite element method (FEM) is chosen to describe the transport system [11]. The calculation was carried out for the different start and stop modes of two operating transport systems with an elastic element of the CDI five-element composite model. The length of one of the conveyors was $9 \mathrm{~km}$. The article [12] presents a comparative analysis of elastic element models: Vogit element and Maxwell element. A system of Lagrange equations was chosen to model the transport system. For the conveyor section, the calculation for speed, acceleration and tension in the belt for several modes of operation is performed. In [13], for the model of the elastic element Maxwell element and the model of the Winkler foundation transport system, a calculation was made for the speed of the conveyor belt. The article [14] presents the calculated "belt stretch curve" and "velocity curves" for the Kelvin-Voigt element model of the elastic element and the transport system model represented by the Lagrange system of equations. The article [15] analyzes the models of the elastic element Kelvin-Voigt element, the combination of Hooke and Kelvin-Voigt element, as well as the combination of two Kelvin-Voigt elements. The analysis of long-wave oscillations in the conveyor belt of the transport system for the Hooke element model and the analytical model of the transport system is presented in [1]. The mechanical properties of composite materials for the manufacture of a rubber conveyor belt with polyester and polyamide cartridges are given in [16]. The results of experimental studies of composite materials of a rubber conveyor belt with polyester and polyamide cartridges are presented. As a result of experimental studies, values were obtained for the tensile strength, elastic modulus, Poisson's ratio for new and operated rubber conveyor belts. Analysis of these indicators, which characterize the properties of a specific material of the conveyor belt, allows you to determine the model of the elastic element, and, accordingly, the type of dependence between the tension and the relative deformation.

\section{CONVEYOR TYPE PRODUCTION LINE MODEL} (Fig. 1):

In this paper, the Kelvin-Voigt element model will be used to analyze the arising stresses in the conveyor belt

$$
\sigma(t, S)=E \varepsilon(t, S)+\eta \frac{d \varepsilon(t, S)}{d t}
$$

where $E$ is the elastic modulus of the element; $\eta$ is element viscosity.

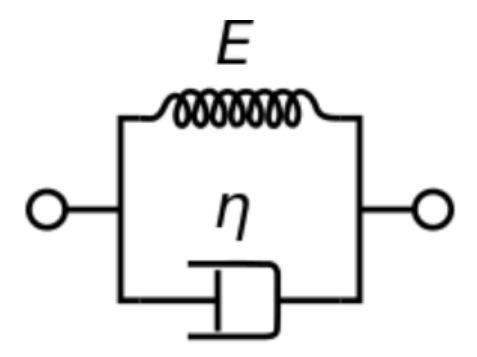

Figure 1. Kelvin-Voigt element

Equation (7) is used to calculate the normal tensions of an element. If the tension is constant $\sigma(t, S)=\sigma_{0}=$ const , then the equation has a solution

$$
\varepsilon(t, S)=\frac{\sigma_{0}}{E}\left(1-e^{-t / t_{0}}\right), \quad t_{0}=\frac{\eta}{E} .
$$

At $t>t_{0}$, the limiting value for the element deformation is obtained:

$$
\lim _{t \rightarrow \infty} \varepsilon(t, S)=\frac{\sigma_{0}}{E} .
$$

At $\omega<<\omega_{\eta}$, the limit transition to the model of an elastic element follows, in which the stress and strain can be calculated in accordance with Hooke's law: 


$$
\sigma(t, S) \approx E \varepsilon(t, S), \quad E \varepsilon(t, S)>>\eta \omega \varepsilon(t, S), \quad \frac{d \varepsilon(t, S)}{d t} \approx \omega \varepsilon(t, S), \quad \frac{\eta}{E}=\frac{1}{\omega_{\eta}}
$$

The analysis of the arising deformations in accordance with Hooke's law was investigated in [1]. Substituting expression (7), which determines the relationship between stress and strain, into equation (6), we obtain

$$
\frac{d\langle\mu\rangle}{d t}=\frac{B h E}{\left([\chi]_{0}(t, S)+[\chi]_{0 C}\right)} \frac{\partial \varepsilon(t, S)}{\partial S}+\frac{B h \eta}{\left([\chi]_{0}(t, S)+[\chi]_{0 C}\right)} \frac{\partial^{2} \varepsilon(t, S)}{\partial t \partial S}-\frac{1}{\left([\chi]_{0}(t, S)+[\chi]_{0 C}\right)} \frac{\partial F_{W}}{\partial S} .
$$

Let us introduce the absolute elongation of the conveyor belt $W(t, S)$ at the moment of time $t$ for the technological position $S$. The ratio of the elongation $d W(t, S)$ of the element by the conveyor belt to the length of the segment $d S$ is the relative deformation of the element

$$
\varepsilon(t, S)=\frac{\partial W(t, S)}{\partial S}, \quad \varepsilon(t, S) \approx 10^{-2} .
$$

The speed of the conveyor belt $\langle\mu\rangle$, on which the material is located, consists of the speed of the belt in equilibrium $\mu_{\psi}$ and the oscillatory part of the belt speed $\frac{d W(t, S)}{d t}$ :

$$
\langle\mu\rangle=\mu_{\psi}+\frac{d W(t, S)}{d t}, \quad \frac{d W(t, S)}{d t}=\frac{\partial W(t, S)}{\partial t}+\langle\mu\rangle \frac{\partial W(t, S)}{\partial S} .
$$

Since the relative deformation of the element $\varepsilon(t, S)$ is small, then

$$
\begin{gathered}
\frac{d W(t, S)}{d t}=\frac{\partial W(t, S)}{\partial t}+\langle\mu\rangle \varepsilon(t, S) \approx \frac{\partial W(t, S)}{\partial t}, \\
|\langle\mu\rangle \varepsilon(t, S)|<<\left|\frac{\partial W(t, S)}{\partial t}\right| .
\end{gathered}
$$

For the relative deformation, represented in the form of a plane wave $W(t, S) \sim e^{i(\omega t-k S)}$, it follows

$$
\langle\mu\rangle<<\left|\frac{\omega}{k}\right|=\frac{1}{2 \pi}\left|\lambda_{k} \omega\right|=\mu_{p h}, \quad \frac{\partial W(t, S)}{\partial t} \sim \omega W(t, S), \quad \varepsilon(t, S)=\frac{\partial W(t, S)}{\partial S} \sim k W(t, S),
$$

where $\omega$ is the oscillation frequency; $k$ is wave vector; $\lambda_{k}$ is disturbance wavelength; $\mu_{p h}$ is the phase velocity of propagation of the disturbance wave, that is, the velocity of movement of a point with a constant phase of oscillatory motion in space, along a given direction. A negative value of the wave vector corresponds to the case of propagation of a backward wave. In this paper, we will consider perturbations whose propagation satisfies the condition (8). Assuming that for the case when the functions $W(t, S),\langle\mu\rangle$ have a large gradient, the destruction of the conveyor belt occurs. Taking this into account, we write down the expression for the change in the speed of the belt, neglecting the values of higher orders of smallness

$$
\frac{d\langle\mu\rangle}{d t} \cong \frac{d \mu_{\psi}}{d t}+\frac{\partial^{2} W(t, S)}{\partial t^{2}}
$$

where the order of smallness is given below:

$$
\frac{\partial^{2} W(t, S)}{\partial t \partial S} \sim \omega k W(t, S), \quad \frac{\partial^{2} W(t, S)}{\partial t^{2}} \sim \omega^{2} W(t, S), \quad \frac{\partial^{2} W(t, S)}{\partial S^{2}} \sim k^{2} W(t, S) .
$$

When the length of a segment $d S$ of the transport route changes, the density changes $\left([\chi]_{0}(t, S)+[\chi]_{0 C}\right)$. Let the length of the segment $d S$ change and become equal $(d S+d W(t, S)), d S>>d W(t, S)$. In this case, the linear density will change and become equal to $\left([\chi]_{0}(t, S)+[\chi]_{0 C}\right)+\left(\Delta[\chi]_{0}(t, S)+\Delta[\chi]_{0 C}\right)$. For a given segment of the transport route, we have

$$
d S\left([\chi]_{0}(t, S)+[\chi]_{0 C}\right)=(d S+d W(t, S))\left([\chi]_{0}(t, S)+[\chi]_{0 C}\right)+\left(\Delta[\chi]_{0}(t, S)+\Delta[\chi]_{0 C}\right)
$$


Neglecting a quantity of the second order of smallness $d W(t, S)\left(\Delta[\chi]_{0}(t, S)+\Delta[\chi]_{0 C}\right)$, we obtain

$$
0 \approx d S\left(\Delta[\chi]_{0}(t, S)+\Delta[\chi]_{0 C}\right)+d W(t, S)\left([\chi]_{0}(t, S)+[\chi]_{0 C}\right)
$$

from where

$$
\frac{\partial d W(t, S)}{\partial S} \approx-\frac{\Delta[\chi]_{0}(t, S)+\Delta[\chi]_{0 C}}{[\chi]_{0}(t, S)+[\chi]_{0 C}} \approx \varepsilon
$$

and

$$
\frac{B h E}{\left([\chi]_{0}(t, S)+[\chi]_{0 C}\right)} \approx C_{\psi}^{2}(t, S)(1-\varepsilon), \quad C_{\psi}^{2}(t, S)=\frac{B h E}{[\chi]_{0 \psi}(t, S)+[\chi]_{0 C}} .
$$

The function $C_{\psi}{ }^{2}(t, S)$ determines the speed of propagation of disturbances along the conveyor belt [8]. The local change in density as a result of stretching the belt does not significantly affect the propagation of stress disturbances along the conveyor belt. Thus, we represent equation (8) in the form

$$
\frac{\partial^{2} W(t, S)}{\partial t^{2}}=C_{\psi}^{2}(t, S) \frac{\partial^{2} W(t, S)}{\partial S^{2}}+C_{\psi}^{2}(t, S) \frac{\eta}{E} \frac{\partial^{3} W(t, S)}{\partial t \partial S^{2}}-\frac{C_{\psi}^{2}(t, S)}{B h E} \frac{\partial F_{W}}{\partial S}-f_{\psi}(t),
$$

where $f_{\psi}(t)$ is the acceleration of the conveyor belt for the steady state

$$
\frac{d \mu_{\psi}}{d t}=f_{\psi}(t)
$$

For horizontal conveyor sections $\cos \delta_{C}=1$, where

$$
\frac{\partial F_{W}}{\partial S}=C f_{C} g_{m}\left([\chi]_{0 R}+\left([\chi]_{0}(t, S)+[\chi]_{0 C}\right)\right) .
$$

The solution of the equation for the case

$$
E \frac{\partial^{2} W(t, S)}{\partial S^{2}}>>\frac{\partial^{3} W(t, S)}{\partial t \partial S^{2}}, \quad \frac{E}{\eta}>>\omega
$$

is presented in [1]. In this paper, we consider the case for which the relation $E / \eta \approx \omega \quad$.

Let's assume that at the initial moment of time the linear density of the material is distributed along the transport route according to the law

$$
[\chi]_{0}(0, S) \approx[\chi]_{0 \psi}(0, S)=\mathrm{H}(S) \Psi(S), \quad \mathrm{H}(S)=\left\{\begin{array}{l}
0, S<0, \\
1, S \geq 0,
\end{array} \quad S \in\left[0 ; S_{d}\right] .\right.
$$

Let us supplement the system of equations (10) with boundary conditions for the equation describing oscillatory processes in the transport system. The tensions $\sigma(t, 0)$ and $\sigma\left(t, S_{d}\right)$ are determined by the tension forces of the conveyor belt $T_{1}$ and $T_{4}$ (Fig. 2).

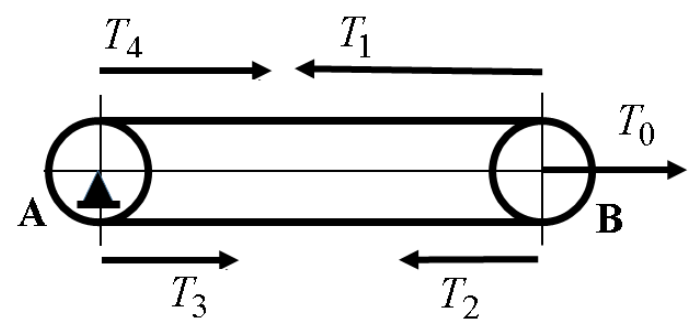

Figure 2. Conveyor belt tension diagram

Let us write the system of equations for the forces $T_{\mathrm{i}}$, that determine the movement of the belt at the characteristic points of the horizontal conveyor section: 


$$
\begin{aligned}
& T_{1}=T_{2} \exp \left(k_{b} \alpha\right) ; \quad T_{3}=T_{2}+F_{\mathrm{W}(2-3)}+F_{\psi(2-3)} ; \quad T_{4}=k_{s} T_{3}, \quad T_{1}=T_{4}+F_{\mathrm{W}(4-1)}+F_{\psi}(4-1), \\
& F_{\mathrm{H}(2-3)}=S_{d} \cdot f_{C} \cdot g_{m}\left([\chi]_{0 R}+[\chi]_{0 C}\right), \\
& F_{\mathrm{N}(2-3)}=(C-1) F_{\mathrm{H}(2-3)}, \\
& F_{\mathrm{H}(4-1)}=F_{\mathrm{H}(2-3)}+f_{C} \cdot g_{m} \int_{0}^{S_{d}}[\chi]_{0}(t, S) d S, \delta_{C}=0 \text {, } \\
& F_{\mathrm{N}(4-1)}=(C-1) F_{\mathrm{H}(4-1)}, \\
& F_{\mathrm{St}(2-3)}=S_{d} \cdot \sin \delta_{C} \cdot g_{m}[\chi]_{0 C}=0, \\
& F_{\mathrm{St}(4-1)}=F_{\mathrm{St}(2-3)}+\sin \delta_{C} \cdot g_{m} \int_{0}^{S_{d}}[\chi]_{0}(t, S) d S=0, \\
& F_{\psi(2-3)}=f_{\psi}(t)[\chi]_{0 C} S_{d}, \\
& F_{\psi(4-1)}=F_{\psi}(2-3)+f_{\psi}(t) \int_{0}^{S_{d}}[\chi]_{0}(t, S) d S, \\
& \mathrm{~F}_{\mathrm{W}}=\mathrm{F}_{\mathrm{H}}+\mathrm{F}_{\mathrm{N}}+\mathrm{F}_{\mathrm{St}}+\mathrm{F}_{\mathrm{S}}
\end{aligned}
$$

where $F_{\psi(2-3)}, F_{\psi(4-1)}$ are forces associated with the acceleration or deceleration of the conveyor belt. We believe that the effects associated with a change in the angular speed of rotation of the drum are small due to the insignificant value of the moment of inertia of the rollers. The solution of the system of equations (11) makes it possible to determine the tractive effort for the transport conveyor for a steady motion:

$$
T_{1}=\left(k_{S} F_{\mathrm{W}(2-3)}+k_{S} F_{\psi}(2-3)+F_{\mathrm{W}(4-1)}+F_{\psi}(4-1)\right) \frac{\exp \left(k_{b} \alpha\right)}{\exp \left(k_{b} \alpha\right)-k_{S}}, T_{4}=T_{1}-F_{\mathrm{W}(4-1)}-F_{\psi}(4-1),
$$

where $k_{b}$ is the coefficient of adhesion between the drum and the belt; $k_{s}$ is drum loss factor "A"; $\alpha$ is total belt wrap angle of drive drums. For steel drum without moisture is $k_{b} \approx 0.3, k_{s} \approx 1.03$ [17] and $\alpha=\pi$, we get $\exp \left(k_{b} \alpha\right)=2.56$. In accordance with (9), the expression for the tension in the conveyor belt takes the form

$$
\sigma(t, S) \approx E \frac{\partial W(t, S)}{\partial S}+\eta \frac{\partial^{2} W(t, S)}{\partial t \partial S}
$$

At points $S=0, S=S_{d}$, the conveyor belt is engaged with the drive and driven shafts of the conveyor section. In this regard, it can be assumed that

$$
\left.\frac{d \varepsilon(t, S)}{d t}\right|_{S=0}=\left.\frac{\partial^{2} W(t, S)}{\partial t \partial S}\right|_{S=0}=0,\left.\quad \frac{d \varepsilon(t, S)}{d t}\right|_{S=S_{d}}=\left.\frac{\partial^{2} W(t, S)}{\partial t \partial S}\right|_{S=S_{d}}=0 .
$$

Taking into account the values of the acting forces $T_{1}, T_{4}$, let write down the boundary conditions

$$
\begin{aligned}
& \sigma\left(t, S_{d}\right)=\frac{T_{1}}{B h}=\left.E \frac{\partial W(t, S)}{\partial S}\right|_{S=S_{d}}+\left.\eta \frac{\partial^{2} W(t, S)}{\partial t \partial S}\right|_{S=S_{d}}= \\
& =\frac{1}{B h}\left(k_{S} F_{\mathrm{W}(2-3)}+k_{S} F_{\psi}(2-3)+F_{\mathrm{W}(4-1)}+F_{\psi}(4-1)\right) \frac{\exp \left(k_{b} \alpha\right)}{\exp \left(k_{b} \alpha\right)-k_{S}}, \\
& \sigma(t, 0)=\frac{T_{4}}{B h}=\left.E \frac{\partial W(t, S)}{\partial S}\right|_{S=0}+\left.\eta \frac{\partial^{2} W(t, S)}{\partial t \partial S}\right|_{S=0}=\left.E \frac{\partial W(t, S)}{\partial S}\right|_{S=S_{d}}-\frac{F_{\mathrm{W}(4-1)+F_{\psi}(4-1)}}{B h} .
\end{aligned}
$$

Let us supplement the system of equations with initial conditions. Consider the mode of occurrence of oscillations, assuming that at the initial moment there were no oscillations

$$
\left.\frac{\partial W(t, S)}{\partial t}\right|_{t=0}=0
$$

The tension of the conveyor belt at the initial moment of time is determined by the initial distribution of material along the technological route $\Psi(S)$ and the acceleration of the conveyor belt $f_{\psi}(t)$. Then 


$$
\begin{gathered}
\sigma(0, S)=\sigma(0,0)+\mathrm{F}_{\mathrm{W} \Psi(4-1)(0, S)+F_{\psi \Psi}(4-1)(0, S),} \\
F_{\mathrm{H} \Psi(4-1)}(0, S)=f_{C} \cdot g_{m} \int_{0}^{S}\left([\chi]_{0 R}+[\chi]_{0 C}+\Psi(\zeta)\right) d \zeta, F_{\mathrm{N} \Psi(4-1)}(0, S)=(C-1) F_{\mathrm{H} \Psi(4-1)}(t, S), \quad[\chi]_{0}(0, S)=\Psi(S) \\
F_{\psi \Psi(4-1)}(0, S)=f_{\psi}(0) \int_{0}^{S}\left([\chi]_{0 R}+[\chi]_{0 C}+\Psi(\zeta)\right) d \zeta, \mathrm{F}_{\mathrm{W} \Psi(4-1)}(0, S)=F_{\mathrm{H} \Psi(4-1)}(0, S)+F_{\mathrm{N} \Psi(4-1)}(0, S) .
\end{gathered}
$$

Let us estimate the value of the acceleration of the conveyor belt $f_{\psi}(t)$. Asynchronous motors with phase rotor are usually installed on powerful belt conveyor sections. The acceleration and deceleration of the conveyor belt of a separate section occurs with the help of a rheostat, which sequentially changes the resistance in the rotor circuit. Simulation of starting up of the drive member of a mechanical system is given into [18]. The qualitative characteristic connecting the torque of the electric motor $M_{\text {eng }}$ and the engine speed $n_{\text {eng }}$ is shown in Fig.3 [19], where $M_{\text {eng } 0}$, $n_{\text {eng } 0}$ is the rated torque of the electric motor and the rated engine speed. For the mode of acceleration and deceleration, the relative torque of the electric motor $\left(M_{\text {eng }} / M_{\text {eng }} 0\right)$ fluctuates within insignificant limits with a change in the relative speed $\left(n_{\text {eng }} / n_{\text {eng }} 0\right)$, (Fig.3). If the engine power $N_{\text {eng }}$ is constant, the engine speed $n_{\text {eng }}$ will fluctuate around the rated value $n_{\text {eng } 0}$. Let us estimate the amplitude of the oscillation, which is associated with the uneven flow of material at the input of the conveyor section. We write the engine power through the traction force $T_{1}$, the radius of the drive shaft $r$ and the rotation speed of the drive shaft:

$$
N_{\text {eng }}=T_{1} r \omega, \quad \omega=2 \pi n_{\text {eng }} .
$$

The change in force $T_{1}$ occurs due to uneven material receipt

$$
\frac{d N_{\text {eng }}}{d t}=\frac{d T_{1}}{d t} r \omega+T_{1} r \frac{d \omega}{d t}=\frac{d T_{1}}{d t} r \omega+T_{1} f_{\psi}(t)=0, \quad f_{\psi}(t)=r \frac{d \omega}{d t} .
$$

Assuming for steady motion $f_{\psi 0}(t)=0$, the equation takes the following form

$$
\frac{d M(t)}{d t} \omega \approx M(t) \frac{d \omega}{d t}, \quad \quad \frac{d f_{\psi}(t)}{d t}<<\frac{f_{\psi}(t)}{t_{a}} \quad M(t)=\int_{0}^{S_{d}}\left([\chi]_{0 C}+[\chi]_{0}(t, S)\right) d S,
$$

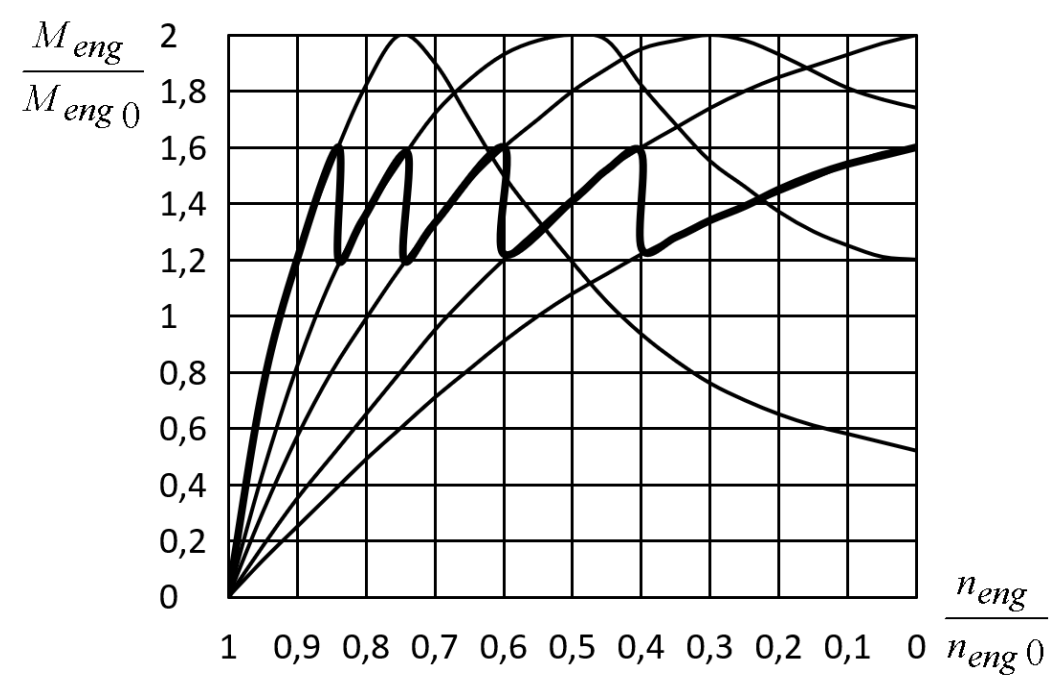

Figure 3. Mechanical characteristic of a phase rotor induction motor

where $M(t)$ is the total weight of the material with a belt for a separate conveyor section; $t_{a}$ is the characteristic duration of the acceleration or deceleration mode. The maximum change in the mass of the material on the conveyor section occurs when the material arrives at the maximum intensity at the entrance of an empty conveyor line. In this 
case, the mass of the belt without material is equal to $M(t)=[\chi]_{0 C} S_{d}$, and the intensity of the incoming flow of material is $\lambda(t) \leq[\chi]_{0 \text { max }} \omega r$. Then

$$
\frac{d \omega}{d t} \approx-\omega \frac{1}{M(t)} \frac{d M(t)}{d t} \approx-\omega \frac{\lambda(t)}{M(t)} \approx-\omega \frac{[\chi]_{0 \max }}{[\chi]_{0 C}} \frac{\omega r}{S_{d}}
$$

Taking into account that

follows

$$
[\chi]_{0 \max } \sim[\chi]_{0 C}, \quad \frac{\omega r}{S_{d}} \sim \frac{1}{T_{d}}
$$

$$
\frac{d \omega}{d t} \approx \frac{\omega}{T_{d}}<<\frac{\omega}{t_{a}}
$$

where $T_{d}$ is the time it takes for the material to pass the transportation route. The inequality allows us to formulate an important result: the uneven flow of material at the entrance of the transport system does not accelerate or decelerate of the conveyor belt. Uneven material flow leads to the destruction of the conveyor belt as a result of shock loads [20].

\section{DIMENSIONLESS MODEL OF CONVEYOR LINE}

Let's introduce dimensionless designations [1, 21, 22]:

$$
\begin{aligned}
& \tau=\frac{t}{T_{d}}, \quad \xi=\frac{S}{S_{d}}, \quad \theta_{0}(\tau, \xi)=\frac{[\chi]_{0}(t, S)}{[\chi]_{0 \max }}, \quad \psi(\xi)=\frac{\Psi(S)}{[\chi]_{0 \max }}, \quad \gamma(\tau)=\lambda(t) \frac{T_{d}}{S_{d}[\chi]_{0 \max }}, \quad g(\tau)=\mu_{\psi}(t) \frac{T_{d}}{S_{d}}, \\
& W_{0}(\tau, \xi)=\frac{W(t, S)}{W_{\max }}, \quad W_{\max }=\frac{\sigma_{b} S_{d}}{E}, \quad \theta_{\mathrm{C}}=\frac{[\chi]_{0 \mathrm{C}}}{[\chi]_{0 \max }}, \quad \theta_{\mathrm{R}}=\frac{[\chi]_{0 \mathrm{R}}}{[\chi]_{0 \max }}, \quad v_{\eta}=\frac{\eta}{E T_{d}}, \\
& v_{b}=\frac{C f_{C} g_{m}\left([\chi]_{0 \max }+[\chi]_{0 C}\right) S_{d}}{\sigma_{b} B h}, \quad v_{f}=v_{f}(\tau)=\frac{\left([\chi]_{0 \max }+[\chi]_{0 C}\right) f_{\psi}(t) S_{d}}{\sigma_{b} B h}, \\
& v_{g}^{2}=\frac{B h E}{[\chi]_{0 \max }+[\chi]_{0 C}}\left(\frac{T_{d}}{S_{d}}\right)^{2}, \quad C_{\psi}^{2}(t, S)=\frac{B h E}{[\chi]_{0 \psi}(t, S)+[\chi]_{0 C}}, \\
& v_{1}^{2}=v_{g}{ }^{2} \frac{1+\theta_{\mathrm{C}}}{\theta_{\mathrm{C}}}, \quad v_{2}^{2}=v_{g}{ }^{2} v_{b}\left(1+\frac{\theta_{\mathrm{R}}}{\theta_{\mathrm{C}}}\right), \quad v_{2 f}=v_{f} v_{g}^{2}=v_{f}(\tau) v_{g}{ }^{2}, \\
& \alpha_{12}=\alpha_{12}(\tau)=v_{b} \frac{\theta_{\mathrm{C}}}{1+\theta_{\mathrm{C}}}\left(1+\frac{\theta_{\mathrm{R}}}{\theta_{\mathrm{C}}}\right)+v_{f}(\tau) \frac{\theta_{\mathrm{C}}}{1+\theta_{\mathrm{C}}}, \quad \alpha_{1}=\alpha_{1}(\tau)=K_{12} \alpha_{12}(\tau), \quad K_{12}=\frac{\left(k_{s}+1\right) \exp \left(k_{b} \alpha\right)}{\exp \left(k_{b} \alpha\right)-k_{S}},
\end{aligned}
$$

where $v_{b}$ determines the ratio of the resistance force $C f_{C} g_{m}\left([\chi]_{0 \max }+[\chi]_{0 C}\right) S_{d}$ at maximum load $[\chi]_{0 \max }$ to the maximum permissible tension force, which ensures the belt break $\sigma_{b} B h ; v_{f}$ is the ratio of the inertia force $\left([\chi]_{0 \max }+[\chi]_{0 C}\right) f_{\psi}(t) S_{d}$ at maximum load $[\chi]_{0 \max }$ and acceleration $f_{\psi}(t)$ to the maximum permissible tensile force, which ensures the belt break $\sigma_{b} B h ; v_{g}=C_{\psi} /\left(S_{d} / T_{d}\right)$ is the relative speed of wave propagation, which is defined as the ratio of the propagation speed of the disturbance wave $C_{\psi}$ to the characteristic speed of the conveyor

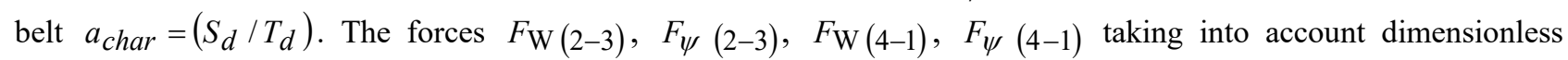
parameters can be written in the form:

$$
\begin{array}{cc}
\frac{F_{\mathrm{W}(2-3)}}{\sigma_{b} B h}=v_{b} \frac{\theta_{\mathrm{C}}+\theta_{\mathrm{R}}}{1+\theta_{\mathrm{C}}}, & \frac{F_{\psi}(2-3)}{\sigma_{b} B h}=v_{f}(\tau) \frac{\theta_{\mathrm{C}}}{1+\theta_{\mathrm{C}}}, \\
\frac{F_{\mathrm{W}(4-1)}}{\sigma_{b} B h}=v_{b} \frac{\theta_{\mathrm{C}}+\theta_{\mathrm{R}}}{1+\theta_{\mathrm{C}}}+v_{b} \int_{0}^{1} \frac{\theta_{0}(\tau, \xi)}{1+\theta_{\mathrm{C}}} d \xi, & \frac{F_{\psi}(4-1)}{\sigma_{b} B h}=v_{f}(\tau) \frac{\theta_{\mathrm{C}}}{1+\theta_{\mathrm{C}}}+v_{f} \int_{0}^{1} \frac{\theta_{0}(\tau, \xi)}{1+\theta_{\mathrm{C}}} d \xi .
\end{array}
$$



form

Then equation (10), which describes the oscillatory processes in the transport system, takes the dimensionless

$$
\begin{gathered}
\frac{\partial^{2} W_{0}(\tau, \xi)}{\partial \tau^{2}}=v_{g}{ }^{2} \frac{\partial^{2} W_{0}(\tau, \xi)}{\partial \xi^{2}} \frac{1+\theta_{\mathrm{C}}}{\theta_{0}(\tau, \xi)+\theta_{\mathrm{C}}}+v_{g}{ }^{2} v_{\eta} \frac{\partial^{3} W_{0}(\tau, \xi)}{\partial \xi^{2} \partial \tau} \frac{1+\theta_{\mathrm{C}}}{\theta_{0}(\tau, \xi)+\theta_{\mathrm{C}}}-v_{g}{ }^{2} \frac{1+\theta_{\mathrm{C}}}{\theta_{\mathrm{C}}} \alpha_{12}+ \\
+v_{g}{ }^{2} v_{b}\left(\frac{\theta_{\mathrm{R}}}{\theta_{\mathrm{C}}}-\frac{\theta_{\mathrm{R}}}{\theta_{0}(\tau, \xi)+\theta_{\mathrm{C}}}\right)
\end{gathered}
$$

with boundary conditions:

$$
\begin{aligned}
\left.\frac{\partial W_{0}(\tau, \xi)}{\partial \xi}\right|_{\xi=1}= & \alpha_{1}+\alpha_{12}\left(\frac{\exp \left(k_{b} \alpha\right)}{\exp \left(k_{b} \alpha\right)-k_{S}}\right) \int_{0}^{1} \frac{\theta_{0}(\tau, \xi)}{\theta_{\mathrm{C}}} d \xi-v_{b} \frac{\theta_{\mathrm{R}}}{\theta_{\mathrm{C}}}\left(\frac{\exp \left(k_{b} \alpha\right)}{\exp \left(k_{b} \alpha\right)-k_{S}}\right) \int_{0}^{1} \frac{\theta_{0}(\tau, \xi)}{\theta_{\mathrm{C}}} d \xi \\
\left.\frac{\partial W_{0}(\tau, \xi)}{\partial \xi}\right|_{\xi=0}= & \left.\frac{\partial W_{0}(\tau, \xi)}{\partial \xi}\right|_{\xi=1}-\frac{F_{\mathrm{W}(4-1)+F_{\psi}(4-1)}}{\sigma_{b} B h}= \\
& =\alpha_{1}+\alpha_{12}\left(\left(\frac{k_{S}}{\exp \left(k_{b} \alpha\right)-k_{S}}\right) \int_{0}^{1} \frac{\theta_{0}(\tau, \xi)}{\theta_{\mathrm{C}}} d \xi-1\right)-v_{b} \frac{\theta_{\mathrm{R}}}{\theta_{\mathrm{C}}}\left(\frac{k_{S}}{\exp \left(k_{b} \alpha\right)-k_{S}}\right) \int_{0}^{1} \frac{\theta_{0}(\tau, \xi)}{\theta_{\mathrm{C}}} d \xi
\end{aligned}
$$

and initial conditions:

$$
\begin{gathered}
\left.\frac{\partial W_{0}(\tau, \xi)}{\partial t}\right|_{t=0}=0 \\
\frac{\partial W_{0}(0, \xi)}{\partial \xi}=\left.\frac{\partial W_{0}(0, \xi)}{\partial \xi}\right|_{\xi=1}-v_{b} \int_{\xi}^{1} \frac{\theta_{\mathrm{C}}+\theta_{\mathrm{R}}+\psi(\xi)}{1+\theta_{\mathrm{C}}} d \xi-\left.v_{f}(\tau) \int_{\xi}^{1} \frac{\theta_{\mathrm{C}}+\psi(\xi)}{1+\theta_{\mathrm{C}}} d \xi\right|_{\tau=0}= \\
=\alpha_{1}(0)+\alpha_{12}(0)\left(\left(\frac{k_{s}}{\exp \left(k_{b} \alpha\right)-k_{S}}\right) \int_{0}^{1} \frac{\psi(\xi)}{\theta_{\mathrm{C}}} d \xi-1+\xi+\int_{0}^{\xi} \frac{\psi(\xi)}{\theta_{\mathrm{C}}} d \xi\right)-v_{b} \frac{\theta_{\mathrm{R}}}{\theta_{\mathrm{C}}}\left(\left(\frac{k_{s}}{\exp \left(k_{b} \alpha\right)-k_{s}}\right) \int_{0}^{1} \frac{\psi(\xi)}{\theta_{\mathrm{C}}} d \xi+\int_{0}^{\xi} \frac{\psi(\xi)}{\theta_{\mathrm{C}}} d \xi\right)
\end{gathered}
$$

\section{ANALYSIS OF THE SOLUTION FOR LOW-LOADED CONVEYOR LINES}

Let us consider a solution for the case of initial conveyor movement when the conveyor line is low loaded. The specific density of the material along such conveyor lines is low compared to the specific gravity of the conveyor belt

$$
\theta_{0}(\tau, \xi) \ll \theta_{\mathrm{C}}, \quad \psi(\xi)=\theta_{0}(0, \xi)<<\theta_{\mathrm{C}} .
$$

Taking into account this assumption, equation (13) takes the form

$$
\frac{\partial^{2} W_{0}(\tau, \xi)}{\partial \tau^{2}}=v_{1}^{2} \frac{\partial^{2} W_{0}(\tau, \xi)}{\partial \xi^{2}}+v_{\eta} v_{1}^{2} \frac{\partial^{3} W_{0}(\tau, \xi)}{\partial \xi^{2} \partial \tau}-v_{1}^{2} \alpha_{12}(\tau)
$$

with boundary conditions:

$$
\left.\frac{\partial W_{0}(t, \xi)}{\partial \xi}\right|_{\xi=1}=\alpha_{1}(\tau),\left.\quad \frac{\partial W_{0}(\tau, \xi)}{\partial \xi}\right|_{\xi=0}=\alpha_{1}(\tau)-\alpha_{12}(\tau),
$$

and initial conditions:

$$
\left.\frac{\partial W_{0}(\tau, \xi)}{\partial t}\right|_{t=0}=0, \quad \frac{\partial W_{0}(0, \xi)}{\partial \xi}=\alpha_{1}(\tau)-\alpha_{12}(\tau)(1-\xi),
$$


During the initial movement of the conveyor belt, three characteristic phases should be distinguished: a) the period of time of the initial start-up, when the conveyor belt from a state of rest turns into movement along the entire route; $b$ ) the phase of the formation of a static force, along the conveyor belt; c) the phase of acceleration of the conveyor belt to the rated speed. Let us dwell on the analysis of the last phase of the start of the conveyor belt. The phase of acceleration of the conveyor belt to the nominal speed is characterized by a quasi constant value of the traction torque (Fig.3), [19] and a quasi constant value of the acceleration of the elements of the conveyor belt. In this regard, the function $v_{f}(\tau)$ will be assumed to be slowly varying during the characteristic time of the acceleration process $t_{a}$.

Let us choose the solution to the equation in the form

$$
W_{0}(\tau, \xi)=W_{00}(\tau, \xi)+W_{01}(\tau, \xi)
$$

Let us represent a function $W_{01}(\tau, \xi)$ as

$$
W_{01}(\tau, \xi)=A(\tau) \xi^{2}+B(\tau) \xi+C_{01} .
$$

where $C_{01}$ is an unknown constant. We define the coefficients $A(\tau), B(\tau)$ in such a way as to ensure the presence of boundary conditions for the function $W_{00}(\tau, \xi)$ in the form

$$
\left.\frac{\partial W_{00}(\tau, \xi)}{\partial \xi}\right|_{\xi=1}=0,\left.\quad \frac{\partial W_{00}(t, \xi)}{\partial \xi}\right|_{\xi=0}=0, \quad \frac{\partial W_{00}(t, \xi)}{\partial \xi}=\frac{\partial W_{0}(t, \xi)}{\partial \xi}-\frac{\partial W_{01}(t, \xi)}{\partial \xi}
$$

This implies the conditions for determining the coefficients $A(\tau), B(\tau)$

$$
\begin{gathered}
\left.\frac{\partial W_{00}(\tau, \xi)}{\partial \xi}\right|_{\xi=1}=\left.\frac{\partial W_{0}(\tau, \xi)}{\partial \xi}\right|_{\xi=1}-\left.\frac{\partial W_{01}(\tau, \xi)}{\partial \xi}\right|_{\xi=1}=\left.\left(\alpha_{1}(\tau)-2 A(\tau) \xi-B(\tau)\right)\right|_{\xi=1}=\alpha_{1}(\tau)-2 A(\tau)-B(\tau)=0, \\
\left.\frac{\partial W_{00}(\tau, \xi)}{\partial \xi}\right|_{\xi=0}=\left.\frac{\partial W_{0}(\tau, \xi)}{\partial \xi}\right|_{\xi=0}-\left.\frac{\partial W_{01}(\tau, \xi)}{\partial \xi}\right|_{\xi=0}=\left.\left(\alpha_{1}(\tau)-\alpha_{21}(\tau)-2 A(\tau) \xi-B(\tau)\right)\right|_{\xi=0}=\alpha_{1}(\tau)-\alpha_{21}(\tau)-B(\tau)=0 .
\end{gathered}
$$

From the solution of the system of equations it follows

$$
\begin{gathered}
A(\tau)=\frac{\alpha_{21}(\tau)}{2}, \quad B(\tau)=\alpha_{1}(\tau)-\alpha_{12}(\tau) \\
W_{0}(\tau, \xi)=W_{00}(\tau, \xi)+\frac{\alpha_{12}(\tau)}{2} \xi^{2}+\left(\alpha_{1}(\tau)-\alpha_{12}(\tau)\right) \xi+C_{01}
\end{gathered}
$$

Substitution $W_{0}(\tau, \xi)$ into (18), an equation for $W_{00}(\tau, \xi)$ is obtained

$$
\frac{\partial^{2} W_{00}(\tau, \xi)}{\partial \tau^{2}}=v_{1}^{2} \frac{\partial^{2} W_{00}(\tau, \xi)}{\partial \xi^{2}}+v_{\eta} v_{1}^{2} \frac{\partial^{3} W_{00}(\tau, \xi)}{\partial \xi^{2} \partial \tau}-\frac{d^{2} \alpha_{12}(\tau)}{d \tau^{2}}\left(\frac{\xi^{2}}{2}-1\right)-\frac{d^{2} \alpha_{1}(\tau)}{d \tau^{2}} \xi+v_{\eta} v_{1}^{2} \frac{d \alpha_{12}(\tau)}{d \tau}
$$

with boundary conditions:

$$
\left.\frac{\partial W_{00}(\tau, \xi)}{\partial \xi}\right|_{\xi=1}=0,\left.\quad \frac{\partial W_{00}(\tau, \xi)}{\partial \xi}\right|_{\xi=0}=0
$$

and initial conditions:

$$
\left.\frac{\partial W_{00}(\tau, \xi)}{\partial \tau}\right|_{\tau=0}=-\left.\frac{d \alpha_{12}(\tau)}{d \tau}\right|_{\tau=0}\left(\frac{\xi^{2}}{2}-\xi\right)-\left.\frac{d \alpha_{1}(\tau)}{d \tau}\right|_{\tau=0} \xi, \quad \frac{\partial W_{00}(0, \xi)}{\partial \xi}=0 .
$$

a) the acceleration of the conveyor belt is absent or constant $v_{f}(\tau)=v_{f 0}=$ const .

If the acceleration value is constant or absent, then by definition $\alpha_{12}(\tau)$ it follows

$$
\frac{d \alpha_{12}(\tau)}{d \tau}=0, \quad \frac{d^{2} \alpha_{12}(\tau)}{d \tau^{2}}=0
$$


and equations (19) take the form

$$
\begin{gathered}
\frac{\partial^{2} W_{00}(\tau, \xi)}{\partial \tau^{2}}=v_{1}^{2} \frac{\partial^{2} W_{00}(\tau, \xi)}{\partial \xi^{2}}+v_{\eta^{2}} v_{1}^{2} \frac{\partial^{3} W_{00}(\tau, \xi)}{\partial \xi^{2} \partial \tau}, \\
\left.\frac{\partial W_{00}(\tau, \xi)}{\partial \xi}\right|_{\xi=1}=0,\left.\quad \frac{\partial W_{00}(\tau, \xi)}{\partial \xi}\right|_{\xi=0}=0, \\
\left.\frac{\partial W_{00}(\tau, \xi)}{\partial \tau}\right|_{\tau=0}=0, \quad \frac{\partial W_{00}(0, \xi)}{\partial \xi}=0 .
\end{gathered}
$$

Let's represent the solution to the problem (20) in the view

$$
W_{00}(\tau, \xi)=\sum_{n=0}^{\infty} T_{n}(\tau) X_{n}(\xi)
$$

Using the boundary conditions for solving the problem, the solution is written as

$$
W_{00}(\tau, \xi)=\sum_{n=0}^{\infty} T_{n}(\tau) \cos (\pi n \xi),
$$

this implies

$$
\frac{d^{2} T_{n}(\tau)}{d \tau^{2}}+(\pi n)^{2} v_{\eta} v_{1}^{2} \frac{d T_{n}(\tau)}{d \tau}+(\pi n)^{2} v_{1}^{2} T_{n}(\tau)=0 .
$$

Let us search a solution to the equation in the form $T_{n}(\tau)=\exp \left(p_{n} \tau\right)$. Substituting $T_{n}(\tau)$ into the original equation, carrying out the differentiation and after cancellation by $\exp \left(p_{n} \tau\right)$, the equation is obtained, that determines the parameter $p_{n}$

$$
\begin{gathered}
p_{n}{ }^{2}+2 \gamma_{n} p_{n}+\omega_{n}{ }^{2}=0, \\
\gamma_{n}=\frac{v_{\eta}}{2}\left(\pi n v_{1}\right)^{2}=\frac{v_{\eta}}{2} \omega_{n}{ }^{2}, \\
p_{n 1,2}=-\gamma_{n} \pm \sqrt{\gamma_{n}{ }^{2}-\omega_{n}{ }^{2}} .
\end{gathered} \quad \omega_{n}{ }^{2}=\left(\pi n v_{1}\right)^{2},
$$

Of particular interest in the analysis of conveyor-type transport systems is the case $0<\gamma_{n}<\omega_{n}$

$$
p_{n 1,2}=-\gamma_{n} \pm i \omega_{p n}, \quad \omega_{p n}=\sqrt{\omega_{n}^{2}-\gamma_{n}^{2}} .
$$

Let's represent the solution as

$$
T_{n}(\tau)=C_{1 n} \exp \left(p_{n 1} \tau\right)+C_{2 n} \exp \left(p_{n 2} \tau\right),
$$

and determine the constants of integration from the initial conditions

$$
p_{n 1} C_{1 n}+p_{n 2} C_{2 n}=0, \quad C_{1 n}+C_{2 n}=0 .
$$

Thus, if there is a constant acceleration of the conveyor belt under the considered boundary and initial conditions, there are no oscillations in the belt.

b) the acceleration of the conveyor belt is linearly dependent on time $v_{f}(\tau)=v_{f 0}+v_{f 1} \tau$.

With a linear dependence of acceleration on time

$$
\frac{d \alpha_{12}(\tau)}{d \tau}=v_{f 1} \frac{\theta_{\mathrm{C}}}{1+\theta_{\mathrm{C}}}, \quad \frac{d^{2} \alpha_{12}(\tau)}{d \tau^{2}}=0
$$

equation (19) takes the form

$$
\frac{\partial^{2} W_{00}(\tau, \xi)}{\partial \tau^{2}}=v_{1}^{2} \frac{\partial^{2} W_{00}(\tau, \xi)}{\partial \xi^{2}}+v_{\eta} v_{1}^{2} \frac{\partial^{3} W_{00}(\tau, \xi)}{\partial \xi^{2} \partial \tau}+v_{\eta} v_{1}^{2} v_{f 1} \frac{\theta_{\mathrm{C}}}{1+\theta_{\mathrm{C}}}
$$




$$
\begin{array}{ll}
\left.\frac{\partial W_{00}(\tau, \xi)}{\partial \xi}\right|_{\xi=1}=0, & \left.\frac{\partial W_{00}(\tau, \xi)}{\partial \xi}\right|_{\xi=0}=0, \\
\left.\frac{\partial W_{00}(\tau, \xi)}{\partial \tau}\right|_{\tau=0}=-v_{f 1} \frac{\theta_{\mathrm{C}}}{1+\theta_{\mathrm{C}}}\left(\frac{\xi^{2}}{2}-\xi+K_{12} \xi\right), & \frac{\partial W_{00}(0, \xi)}{\partial \xi}=0 .
\end{array}
$$

Let us search a solution to the problem in the form of an expansion in a Fourier series in $\xi$

$$
W_{00}(\tau, \xi)=T_{0}(\tau)+\sum_{n=1}^{\infty} T_{n}(\tau) \cos (\pi n \xi),
$$

considering $\tau$ as a parameter. To find $W_{00}(\tau, \xi)$ we define the functions $T_{n}(\tau)$. Let us write the initial conditions in the form of Fourier series:

$$
\left.\frac{\partial W_{00}(\tau, \xi)}{\partial \tau}\right|_{\tau=0}=\frac{a_{0}}{2}+\sum_{n=1}^{\infty} a_{n} \cos (\pi n \xi), \quad a_{n}=\left.2 \int_{0}^{1} \frac{\partial W_{00}(\tau, \xi)}{\partial \tau}\right|_{\tau=0} \cos (\pi n \xi) d \xi .
$$

Let's define the coefficients $a_{n}$

$$
a_{0}=-2 v_{f 1} \frac{\theta_{\mathrm{C}}}{1+\theta_{\mathrm{C}}}\left(\frac{K_{12}}{2}-\frac{1}{3}\right), \quad a_{n}-2 v_{f 1} \frac{\theta_{\mathrm{C}}}{1+\theta_{\mathrm{C}}}\left(\frac{1}{(\pi n)^{2}}+K_{12} \frac{(-1)^{n}-1}{(\pi n)^{2}}\right),
$$

substitute the expected form of the solution $W_{00}(\tau, \xi)$ in $(21)$

$$
\begin{aligned}
& \frac{d^{2} T_{0}(\tau)}{d \tau^{2}}=v_{\eta} v_{1}^{2} v_{f 1} \frac{\theta_{\mathrm{C}}}{1+\theta_{\mathrm{C}}}, \\
& T_{0}(0)=0, \quad, \quad \frac{d T_{0}(0)}{d \tau}=-v_{f 1} \frac{\theta_{\mathrm{C}}}{1+\theta_{\mathrm{C}}}\left(\frac{K_{12}}{2}-\frac{1}{3}\right), \\
& \frac{d^{2} T_{n}(\tau)}{d \tau^{2}}+v_{\eta} v_{1}^{2}(\pi n)^{2} \frac{d T_{n}(\tau)}{d \tau}+v_{1}^{2}(\pi n)^{2} T_{n}(\tau)=0, \\
& \frac{d T_{n}(0)}{d \tau}=-2 v_{f 1} \frac{\theta_{\mathrm{C}}}{1+\theta_{\mathrm{C}}}\left(\frac{1}{(\pi n)^{2}}+K_{12} \frac{(-1)^{n}-1}{(\pi n)^{2}}\right),
\end{aligned}
$$

The solution to equation (22) has the form

$$
T_{0}(\tau)=v_{f 1} \frac{\theta_{\mathrm{C}}}{1+\theta_{\mathrm{C}}}\left(v_{\eta} v_{1}^{2} \frac{\tau^{2}}{2}-\left(\frac{K_{12}}{2}-\frac{1}{3}\right) \tau\right) .
$$

Let's search for the solution to equation (23) in the form $T_{n}(\tau)=\exp \left(p_{n} \tau\right)$. Substituting $T_{n}(\tau)$ into (23), differentiating and cancelling by $\exp \left(p_{n} \tau\right)$, we obtain the equation that determines the parameter $p_{n}$

$$
\begin{gathered}
p_{n}{ }^{2}+2 \gamma_{n} p_{n}+\omega_{n}{ }^{2}=0 \\
\gamma_{n}=\frac{v_{\eta}}{2}\left(\pi n v_{1}\right)^{2}=\frac{v_{\eta}}{2} \omega_{n}{ }^{2}, \quad \omega_{n}{ }^{2}=\left(\pi n v_{1}\right)^{2} .
\end{gathered}
$$

Consider the form of the solution for the case $0<\gamma_{n}<\omega_{n}$

$$
p_{n 1,2}=-\gamma_{n} \pm i \omega_{p n}, \quad \omega_{p n}=\sqrt{\omega_{n}^{2}-\gamma_{n}^{2}} .
$$


The solution to the equation is searching as

$$
T_{n}(\tau)=C_{1 n} \exp \left(p_{n 1} \tau\right)+C_{2 n} \exp \left(p_{n 2} \tau\right),
$$

the integration constants are determined from the initial conditions

$$
p_{n 1} C_{1 n}+p_{n 2} C_{2 n}=-2 v_{f 1} \frac{\theta_{\mathrm{C}}}{1+\theta_{\mathrm{C}}}\left(\frac{1}{(\pi n)^{2}}+K_{12} \frac{(-1)^{n}-1}{(\pi n)^{2}}\right), \quad C_{1 n}+C_{2 n}=0
$$

wherefrom:

$$
C_{1,2 n}=\mp i \frac{v_{f 1}}{\omega_{p n}} \frac{\theta_{\mathrm{C}}}{1+\theta_{\mathrm{C}}}\left(\frac{1}{(\pi n)^{2}}+K_{12} \frac{(-1)^{n}-1}{(\pi n)^{2}}\right)
$$

After simple transformations, the solution can be represented as

$$
T_{n}(\tau)=e^{-\gamma_{n} \tau} \sin \left(\omega_{p n} \tau\right) \frac{v_{f 1}}{\omega_{p n}} \frac{\theta_{\mathrm{C}}}{\left(1+\theta_{\mathrm{C}}\right)}\left(\frac{1}{(\pi n)^{2}}+K_{12} \frac{(-1)^{n}-1}{(\pi n)^{2}}\right)
$$

This allows us to write the solution for the equation (18). The obtained solution makes it possible to determine the voltage value in the conveyor belt along the transport route

$$
\frac{\partial W_{0}(\tau, \xi)}{\partial \xi}=-\sum_{n=1}^{\infty} e^{-\gamma_{n} \tau} \sin \left(\omega_{p n} \tau\right) \frac{\nu_{f 1}}{\omega_{p n}} \frac{\theta_{\mathrm{C}}}{\left(1+\theta_{\mathrm{C}}\right)}\left(\frac{1}{(\pi n)}+K_{12} \frac{(-1)^{n}-1}{(\pi n)}\right) \sin (\pi n \xi)+\alpha_{12}(\tau) \xi+\alpha_{1}(\tau)-\alpha_{12}(\tau)
$$

Over time, the amplitude of fluctuations in the magnitude of dynamic stresses decreases exponentially, so that after a time of the order of several $\tau_{n} \sim \frac{1}{\gamma_{n}}$, the oscillations completely damp out. The decay time of oscillations is inversely proportional to the square of the circular frequency of oscillations $\tau_{n} \sim \omega_{n}{ }^{-2}$.

\section{CONCLUSION}

Changing the acceleration mode of the conveyor belt of the transport system is one of the sources of dynamic stresses along the conveyor belt. At the same time, the mechanical properties of composite materials that are used for the manufacture of conveyor belts have a significant effect on the occurrence of elastic vibrations and their propagation. The use of composite materials with mechanical properties corresponding to the Kelvin-Voigt model of an elastic element ensures damping of the resulting elastic vibrations. The paper investigates two modes of acceleration of the conveyor belt: constant acceleration mode and acceleration ramping over time. It has been demonstrated that the mode of movement of a conveyor belt with a linear change in the magnitude of acceleration in time is the cause of the occurrence of dynamic tensions. The damping rate of vibrations is proportional to the viscosity of the elastic element and the square of the vibration frequency in the transport system. The magnitude of the generated dynamic tensions is determined by the amplitudes of the oscillations of the first harmonics. During the characteristic time of change $\tau_{1} \sim \gamma_{1}^{-1}$, the amplitude of oscillations for $n=2$ will decrease by $e^{4} \approx 0.5 \cdot 10^{2}$ times, for $n=3$ will decrease by $e^{9} \approx 10^{4}$ times. The system exhibits low-frequency oscillations of the first harmonics with a characteristic dimensionless time $\tau_{n} \sim \gamma_{n}{ }^{-1}$ of variation of the oscillation amplitude and, therefore, the oscillation energy. The use of composite materials with a high value of the viscosity coefficient ensures attenuation of the arising dynamic stresses, which increases the reliability and durability of the functioning of transport systems.

\section{ORCID-IDs}

(1) Oleh M. Pihnastyi, https://orcid.org/0000-0002-5424-9843; Dalery D. Khodusov, https://orcid.org/0000-0003-1129-3462 


\section{REFERENCES}

[1] O.M. Pihnastyi, and V.D. Khodusov, East European Journal of Physics, 1, 121-136 (2020), https://doi.org/10.26565/23124334-2020-1-11.

[2] O.M. Pihnastyi, and V.D. Khodusov, Bulletin of the South Ural State University. Ser. Mathematical Modelling, Programming \& Computer Software (Bulletin SUSUMMCS), 10, 67-77 (2017), https://doi.org/10.14529/mmp170407.

[3] O.M. Pihnastyi, Scientific bulletin of National Mining University, 4, 104-111 (2017), http://nbuv.gov.ua/UJRN/Nvngu 2017418.

[4] DIN 22101:2002-08. Continous conveyors. Belt conveyors for loose bulk materials. Basics for calculation and dimensioning. [Normenausschuss Bergbau (FABERG), DIN Deutsches Institut für Normung e.v. Normenausschuss Maschinenbau (NAM)], (2002), pp.51.

[5] Ju. Razumnyj, A. Ruhlov, and A. Kozar, Mining Electromechanics and Automation, 76, 24-28 (2006). https://docplayer.ru/64655888-Povyshenie-energoeffektivnosti-konveyernogo-transporta-ugolnyh-shaht.html

[6] M. Alspaugh, in: MINExpo-2004, (New York,Las Vegas, NV, USA, 2004), pp. 17-27 (2004), http://fliphtml5.com/pfyf/pccg/basic.

[7] SIMINE for conveyors. Siemens. (2020), https://new.siemens.com/global/en/markets/mining-industry/transport/conveyorsystems.html

[8] R. Pascual, V. Meruane, and G. Barrientos, in: XXVI Iberian Latin-American Congress on Computational Methods in Engineering (CILAMCE-2005, Santo, Brazil, 19th-21st October 2005), Paper CIL0620, (2005), pp. 1-15, http://citeseerx.ist.psu.edu/viewdoc/download?doi=10.1.1.494.34\&rep=rep1\&type=pdf

[9] L.K. Nordell, Z.P. Ciozda, Bulk Solids Handling, http://www.ckit.co.za/secure/conveyor/papers/troughed/transient/transient-belt-stresses.htm

[10] X. Li. J. Pang, and Z. Kou, Shock and Vibration, 1(1-6), 769309, (2015) http://downloads.hindawi.com/journals/sv/2015/769309.pdf

[11] T. Mathaba, and X. Xia, Energies, 8(12), 13590-13608 (2015), https://doi.org/10.3390/en81212375

[12] G. Yang, Sensors and Transducers, 181(10), 210-218 (2014), https://www.sensorsportal.com/HTML/DIGEST/P 2492.htm.

[13] Yan Lu, Fu-Yan Lin and Yu-Chao Wang, Journal of Theoretical and Applied Mechanics, 45(3), 53-68 (2015), https://content.sciendo.com/view/journals/jtam/45/3/article-p53.xml

[14] Sanjay G. Sakharwade, Shubharata Nagpal, International Journal of Mathematical, Engineering and Management Sciences, 4(5), 1169-1179 (2019), https://dx.doi.org/10.33889/IJMEMS.2019.4.5-092

[15] P. Kulinowski, Archives of Mining Sciences, 59(1), 123-138 (2014), DOI 10.2478/amsc-2014-0009 https://journals.pan.pl/dlibra/show-content?id=93449\&/simulation-method-of-designing-and-selecting-tensioning-systems-formining-belt-conveyors-kulinowski-piotr?language $=$ en

[16] M. Manjgo, E. Piric, T. Vuherer, and M. Burzic, Annals of the Faculty of Engineering Hunedoara, 16(1), 141-144 (2018). http://annals.fih.upt.ro/pdf-full/2018/ANNALS-2018-1-22.pdf

[17] V.V. Degtjarev, Нормирование топливно-энергетических ресурсов и регулирование режимов энергопотребления [Rationing of fuel and energy resources and regulation of energy consumption modes], (Nedra, Moscow, 1983), pp. 225, http://www.xn--80affsqimkl5h.xn--p1ai/_ld/7/735 _-.pdf. (in Russian)

[18] S. Gramblička, R. Kohár, and M. Stopka, Procedia Engineering, 192, 259-264 (2017). https://doi.org/10.1016/j.proeng.2017.06.045

[19] A.O. Spivakovsky and V.A. Dyachkov, Транспортные машины [Transporting machines], (Mechanical Engineering, Moscow, 1983), pp. 487. (in Russian)

[20] B. Karolewski, and D. Marasova, Maintenance and reliability, 16(2), 229-235. (2014), http://www.ein.org.pl/sites/default/files/2014-02-09.pdf

[21] N.A. Azarenkov, O.M. Pihnastyi, and V.D. Khodusov, Reports of the National Academy of Sciences of Ukraine, 2, 29-35 (2011), http://dspace.nbuv.gov.ua/handle/123456789/37227.

[22] O.M. Pihnastyi, Problems of Atomic science and technology, 3, 322-325 (2007), http://dspace.nbuv.gov.ua/handle/123456789/111018.

\section{ГШДРОДИНАМІЧНА КЕLVIN-VOIGT МОДЕЛЬ ТРАНСПОРТНОЇ СИСТЕМИ}

О.М. Пігнастий

${ }^{a}$ Національний технічний університет «ХПI», 61002

Украӥна, м. Харків, вул. Кирпичева, 2

${ }^{b}$ Харківський національний університет імені В.Н. Каразіна

61022, Україна, Харків, м. Свободи, 4

Розглянуто гідродинамічна Kelvin-Voigt модель виробничих систем 3 потоковим методом організації виробництва. Визначено основні макропараметри стану виробничої лінії і взаємозв'язку між ними. Представлений аналіз основних характеристик моделей пружних елементів, які використані для аналізу виникнення динамічних напружень в рухомій конвеєрній стрічці. Сформульовано крайову задачу для пружних поздовжніх коливань в конвеєрній стрічці 3 рухомим матеріалом. Передбачається, що деформація елемента стрічки конвеєра відповідає Kelvin-Voigt моделі і ковзання рухомого матеріалу по стрічці відсутній. При визначенні сил опору руху, діючих на одиничний елемент стрічки, використані рекомендації DIN 22101: 2002-08. Проведено аналіз Kelvin-Voigt моделі пружного елемента і продемонстровані відмінні риси моделі. Дано обгрунтування вибору Kelvin-Voigt моделі пружного елемента для опису процесу виникнення пружних поздовжніх коливань в конвеєрній стрічці. Оцінена залежність нерівномірного надходження потоку матеріалу і величини напружень в стрічці. Записано вираз для швидкості розповсюдження збурень вздовж рухається конвеєрної стрічки 3 матеріалом. Визначено причини прискорення і гальмування конвеєрної стрічки, пов'язані з нерівномірним надходженням матеріалу на вхід транспортної системи. Продемонстровано зв'язок між швидкістю руху конвеєрної стрічки і масою матеріалу уздовж секції конвеєра. Показано, що збільшення потужності електродвигуна при старті і прискоренні конвеєрної стрічки, а також зменшення потужності при гальмуванні і зупинці конвеєрної стрічки $є$ причиною виникнення в ній динамічних напружень. Аналізуються характерні фази початкового руху конвеєрної стрічки з матеріалом. Досліджено процес виникнення динамічних напружень з постійним і змінним прискоренням конвеєрної стрічки для фази розгону і гальмування конвеєрної стрічки. Для 
аналізу використана модель конвеєрної лінії в безрозмірному вигляді. Отримано вираз для статичних і динамічних напружень в конвеєрній стрічці. Оцінена амплітуда коливань динамічних напружень і характерний час загасання коливань в конвеєрній стрічці. Продемонстровано квадратична залежність швидкості загасання хвилі динамічних напружень зі збільшенням частоти коливання. Показана обернено пропорційна залежність характерного часу загасання виникли динамічних напружень від величини коефіцієнта в'язкості композиційного матеріалу конвеєрної стрічки.

КЛЮЧОВІ СЛОВА: гідродинамічна модель транспортної системи, двох моментное опис виробництва, Kelvin-Voigt модель, балансові рівняння, PDE-модель виробництва

\author{
ГИДРОДИНАМИЧЕСКАЯ КЕLVIN-VOIGT МОДЕЛЬ ТРАНСПОРТНОЙ СИСТЕМЫ \\ О.М. Пигнастый ${ }^{a}$ В.Д. Ходусов

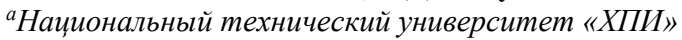 \\ 61002, Украина, г. Харьков, ул. Кирпичева, 2 \\ ${ }^{b}$ Харьковский национальный университет имени В.Н. Каразина \\ 61022, Украина, Харьков, пл. Свободы, 4
}

Рассмотрена гидродинамическая Kelvin-Voigt модель производственных систем с потоковым методом организации производства. Определены основные макропараметры состояния производственной линии и взаимосвязи между ними. Представлен анализ основных характеристик моделей упругих элементов, которые использованы для анализа возникновения динамических напряжений в движущейся конвейерной ленте. Сформулирована краевая задача для упругих продольных колебаний в конвейерной ленте с движущимся материалом. Предполагается, что деформация элемента ленты конвейера соответствует Kelvin-Voigt модели и скольжение движущегося материала по ленте отсутствует. При определении сил сопротивления движению, действующих на единичный элемент ленты, использованы рекомендации DIN 22101: 2002-08. Проведен анализ Kelvin-Voigt модели упругого элемента и продемонстрированы отличительные особенности модели. Дано обоснование выбора Kelvin-Voigt модели упругого элемента для описания процесса возникновения упругих продольных колебаний в конвейерной ленте. Оценена зависимость неравномерного поступления потока материала и величины напряжений в ленте. Записано выражение для скорости распространения возмущений вдоль движущейся конвейерной ленты с материалом. Определены причины ускорения и торможения конвейерной ленты, связанные с неравномерным поступлением материала на вход транспортной системы. Продемонстрирована связь между скоростью движения конвейерной ленты и массой материала вдоль секции конвейера. Показано, что увеличение мощности электродвигателя при старте и ускорении конвейерной ленты, а также уменьшение мощности при торможении и остановке конвейерной ленты является причиной возникновения в ней динамических напряжений. Анализируются характерные фазы начального движения конвейерной ленты с материалом. Исследован процесс возникновения динамических напряжений с постоянным и переменным ускорением конвейерной ленты для фазы разгона и торможения конвейерной ленты. Для анализа использована модель конвейерной линии в безразмерном виде. Получено выражение для статических и динамических напряжений в конвейерной ленте. Оценена амплитуда колебаний динамических напряжений и характерное время затухания колебаний в конвейерной ленте. Продемонстрирована квадратичная зависимость скорости затухания волны динамических напряжений с увеличением частоты колебания. Показана обратно пропорциональная зависимость характерного времени затухания возникших динамических напряжений от величины коэффициента вязкости композиционного материала конвейерной ленты.

КЛЮЧЕВЫЕ СЛОВА: гидродинамическая модель транспортной системы, двух моментное описание производства, Kelvin-Voigt модель, балансовые уравнения, PDE-модель производства 